\title{
Crown Walls in Mass and Reinforced Concrete: The Way to Aesthetics in Maritime Works
}

\author{
Vicente Negro, Associate Professor, Universidad Politécnica de Madrid, UPM \\ (Spain) \\ Mario Martín-Antón, PhD Student, UPM \\ José María del Campo, Assistant Professor, UPM \\ José Santos López-Gutiérrez, Assistant Professor, UPM \\ M. Dolores Esteban, Assistant Professor, UPM
}

\begin{abstract}
Maritime works are characterized by their remarkable size, length, depth and extraordinarily great demand for natural or artificial materials. To this effect, despite functional designs or the ultimate limit state, a breakwater crown wall can increase the overall effectiveness of the structure in limiting wave overtopping. It will contribute to a reduction of volume of material required and hence the cost to achieve a given level of performance depending on the precautions to be taken on the basis of the critical discharges for functional safety (vehicles, pedestrian and buildings) and structural safety (embankment and revetment seawalls), amongst others.
\end{abstract}

In many cases, bulky mass-concrete elements are designed without any steel reinforcement. Sometimes this effect causes cracking problems in large volumes. The step to slender reinforced concrete elements may take a leap to the aesthetic factor and visual landscape integration in maritime works. In addition, the use of other materials, shapes and colours can bring breakwaters and crown walls to life by creating new functions for maritime works such as a promenade, relaxation or visual enjoyment areas.

The aim of this article is to reflect on the issue of bulky mass concrete elements or rebars in slender reinforced concrete crown walls and how the use of these slender elements can bring with it excellent artistic developments as well as the use of other materials in mass concrete sloping, vertical and composite breakwaters and their crown walls. Some breakwaters are no longer just mere defence works but are becoming pieces of art.

\section{Introduction}

The different shapes, classes and types of breakwater display cross sections with various terminations. The economic perspective of reducing material in sloping breakwaters is one of the variables of interest. It leads to reducing the number of armour layers which are replaced by a crown wall designed using structural and functional criteria. Conversely, the continuation of monolithism with parapets anchored to the caissons or in situ concreted onto their cellular body in vertical breakwaters guarantee their rigidity, operability and use against maritime climate forces.

The British Standard provides different finishes on the basis of repairing and maintaining the layers and quantifying overtopping by functionality factors (Figure 1).

The capability of using anchoring elements allowing for curved walls, greater slenderness, damping chambers, systems taking advantage of wave energy, stress decrease with breather hoses in vertical breakwaters amongst other aspects increases their possibilities. Studying a crown wall has always been approached from the position of thrusts and/or forces on the face and the calculation of run-up and over-topping associated with operations: admissible overtopping rate and volume (EurOtop, 2016). For example, a rate of $q=10 \mathrm{l} / \mathrm{s}$ per $\mathrm{m}$ implies significant overtopping for dikes, seawalls and embankments. 


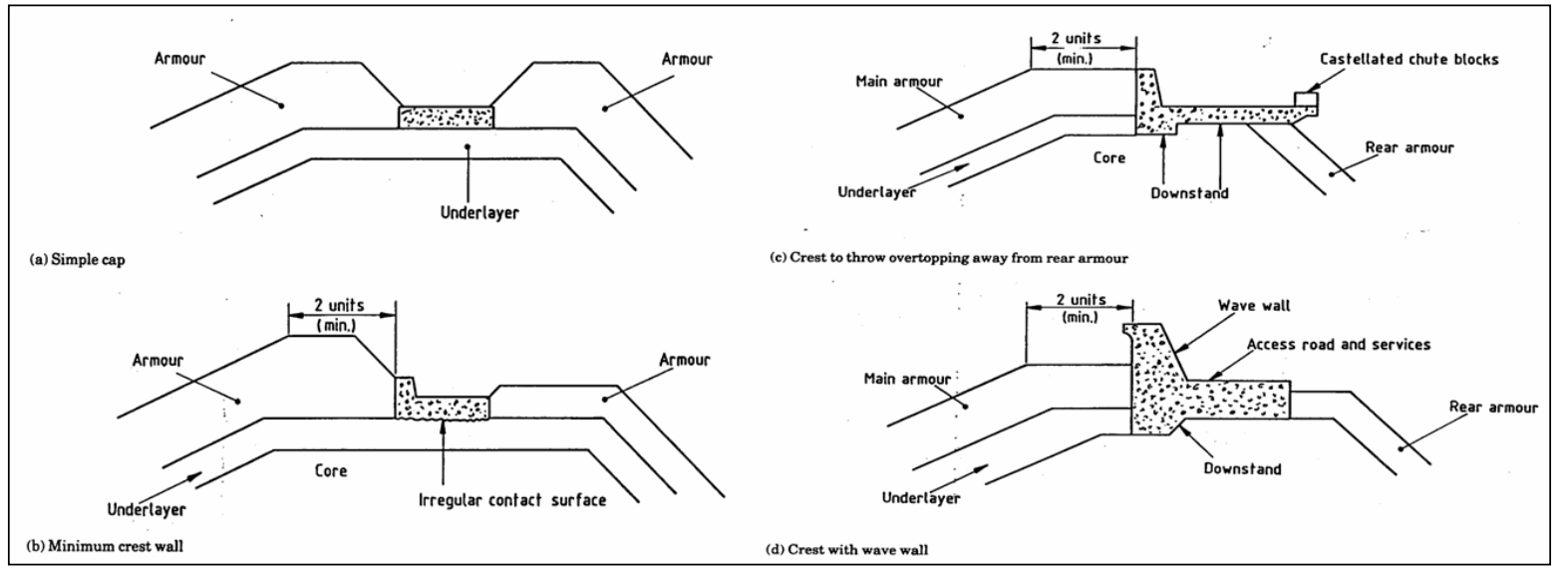

Figure 1: Typical crest structures for rubble mound breakwaters (BSI, 1991)

We have, in the first case, the study relating to pressure diagrams from Iribarren to Günbak \& Göcke and including Bradbury \& Allsop or Pedersen \& Burcharth amongst others (Figure 2).

\begin{tabular}{|c|c|c|c|c|c|c|c|}
\hline \multirow{2}{*}{\multicolumn{2}{|c|}{ Year published }} & $\begin{array}{l}\text { Iribarren and } \\
\text { Nogales }\end{array}$ & $\begin{array}{l}\text { Günbak- } \\
\text { Göcke }\end{array}$ & $\begin{array}{c}\text { Bradbury- } \\
\text { Allsop }\end{array}$ & $\begin{array}{l}\text { Pedersen- } \\
\text { Burcharth }\end{array}$ & $\begin{array}{l}\text { Martín } \\
\text { et al. }\end{array}$ & $\begin{array}{c}\text { Berenguer- } \\
\text { Baonza }\end{array}$ \\
\hline & & 1954 & 1984 & 1988 & 1992 & 1995 & 2006 \\
\hline \multirow[t]{3}{*}{$\begin{array}{l}\text { Test based } \\
\text { on: }\end{array}$} & Waves & No & Regular & - & - & $\begin{array}{l}\text { In situ } \\
\text { measured } \\
\text { campaigns } \\
\text { (Gijón) }\end{array}$ & $\begin{array}{l}\text { Irregular } \\
\text { JONSWAP }\end{array}$ \\
\hline & Slope & No & $\begin{array}{l}\text { Run-up with } \\
5 \mathrm{~V} / 2 \mathrm{H} \\
\text { Pressures with } \\
1 \mathrm{~V} / 2 \mathrm{H}\end{array}$ & $1 \mathrm{~V} / 2 \mathrm{H}$ & $1 \mathrm{~V} / 1 \cdot 5 \mathrm{H}$ & $1 \mathrm{~V} / 1 \cdot 5 \mathrm{H}$ & $\begin{array}{l}\text { Run-up with } \\
1 \mathrm{~V} / 1 \cdot 5 \mathrm{H} \text { and } \\
1 \mathrm{~V} / 2 \mathrm{H} \\
\text { Forces with } \\
1 \mathrm{~V} / 1 \cdot 5 \mathrm{H}\end{array}$ \\
\hline & $\begin{array}{l}\text { Armour layer } \\
\text { units }\end{array}$ & No & Rock fill & $\begin{array}{l}\text { Rock fill and } \\
\text { blocks as per } \\
\text { figures }\end{array}$ & Unspecified & $\begin{array}{l}\text { Rock fill, } \\
\text { cubes, } \\
\text { tetrapods, } \\
\text { quadrapods, } \\
\text { tribar and } \\
\text { dolos }\end{array}$ & $\begin{array}{l}\text { Run-up with } \\
\text { cubes and } \\
\text { perforated } \\
\text { antifers. } \\
\text { Forces with } \\
\text { blocks and } \\
\text { rock fill }\end{array}$ \\
\hline \multicolumn{2}{|l|}{$\begin{array}{l}\text { Formulation } \\
\text { in: }\end{array}$} & $\begin{array}{l}\text { Horizontal } \\
\text { pressures }\end{array}$ & $\begin{array}{l}\text { Horizontal and } \\
\text { vertical } \\
\text { pressures }\end{array}$ & $\begin{array}{l}\text { Horizontal and } \\
\text { vertical forces }\end{array}$ & $\begin{array}{l}\text { Horizontal } \\
\text { forces }\end{array}$ & $\begin{array}{l}\text { Horizontal } \\
\text { and vertical } \\
\text { pressures }\end{array}$ & $\begin{array}{l}\text { Horizontal } \\
\text { and vertical } \\
\text { forces with } \\
\text { their } \\
\text { respective } \\
\text { moments }\end{array}$ \\
\hline \multicolumn{2}{|l|}{ Criteria } & $\begin{array}{l}\text { Geometric and } \\
\text { undulatory }\end{array}$ & $\begin{array}{l}\text { Geometric and } \\
\text { undulatory }\end{array}$ & $\begin{array}{l}\text { Geometric and } \\
\text { undulatory }\end{array}$ & $\begin{array}{l}\text { Geometric } \\
\text { and } \\
\text { undulatory }\end{array}$ & $\begin{array}{l}\text { Geometric } \\
\text { and } \\
\text { undulatory }\end{array}$ & $\begin{array}{l}\text { Geometric } \\
\text { and } \\
\text { undulatory }\end{array}$ \\
\hline
\end{tabular}

Figure 2: Studies of wave pressure diagrams in vertical breakwaters (Negro, 2013)

There are different models of calculation of crown wall stability against the action of the incident waves. Most of them calculate pressures (Iribarren, Günbak, Martín and Berenguer) and forces (Bradbury and Pedersen) on the structure. They determine dynamic, hydrostatic and pseudohydrostatic actions. Some of them are based on small model tests with regular and irregular waves, with two or more units crowning the sloping breakwater and adjusted with real examples, such as the Martín-Losada method with the "Príncipe de Asturias" breakwater in Gijón (Spain) (Martín et al., 1995). Figure 2 shows the different patterns of calculations of crown walls as a function of the incident waves, the type of breakwater, the spectrum analysis, the level of run up, the number of units in the main layer, and so on. 
A second study (Rodríguez et al, 2015) responds to overtopping rate criteria where the numerous models facilitate decision making on the basis of safety for pedestrians, vehicles and buildings (functional) on the rear of defence and protection structures (stability). The design of breakwaters had a structural stage prior to the functional schemes. In the case of rubble mound, the armour layer was the priority element of calculation. In vertical breakwaters, the forces and pressure diagrams were the main aspects to define the effective width of the resistant monoliths. On a second step, the top level and the admissible overtopping discharges rates of the crown wall are studied. It responds to functional analysis, overtopping rate and structure features. These examples represent a state of the art of different calculations in breakwaters.

Maritime works display large volumes of both natural and artificial materials as shown by the large construction works built in Spain during the first decade of the 21st century. The possibilities of combining aesthetics with structure, scenery with the environment, history, heritage and cultural inheritance of construction works enable this element to be reflected within the paths of art and architecture. When a maritime work with these volumes of material is initially proposed, the path that leads from the structural and functional to aesthetics and art is possible.

Forerunners of a singular beauty and in harmony with the surroundings, they can be found in historical constructions where the United Kingdom is a clear example of sensitivity in its curved and/or arched crown walls. Traditional examples, amongst others, are Edinburgh (curved cross section), Fraserburgh and Arbroath in Scotland and Dover or Cobb, Lyme Regis, in England (curved alignment). In some cases, the form not only responds to an aesthetic or structural, but functional reason. Many breakwaters had rail lines to load the goods, so abrupt alignment changes are not allowed on them. This is the case of Seaham (Figures 3 and 4).

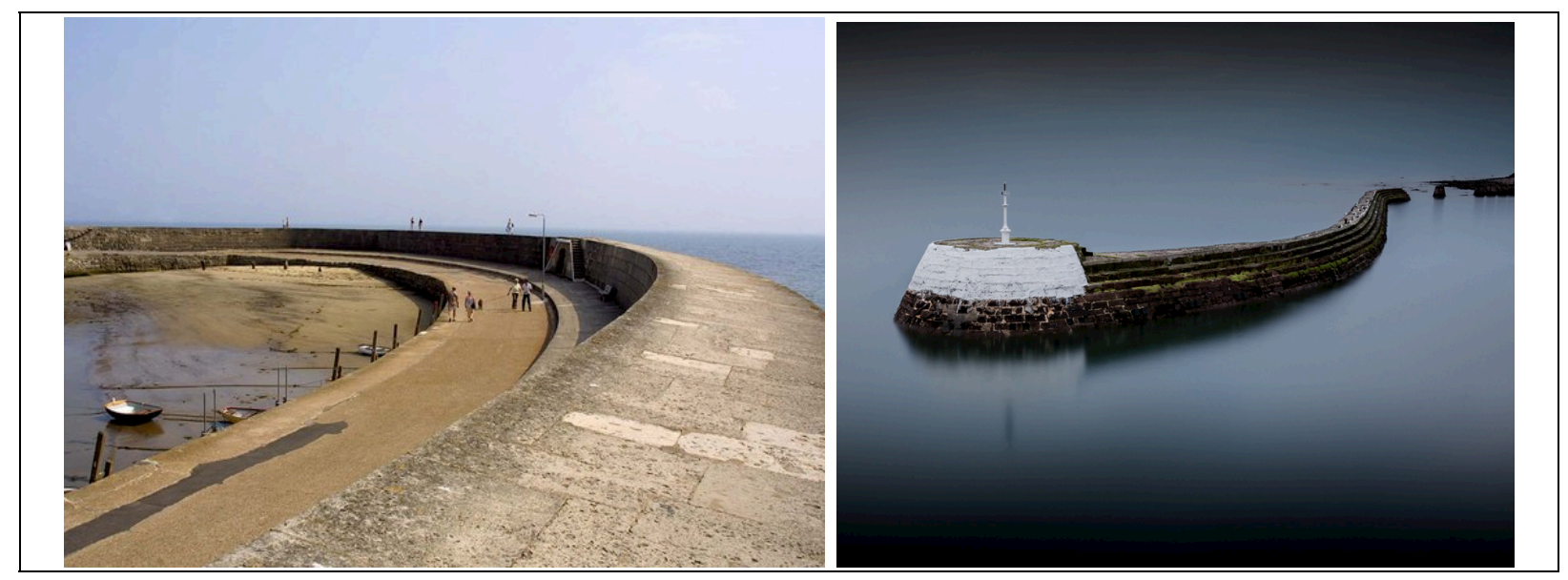

Figure 3: Cobb, Lyme Regis (left) and Arbroath (right)

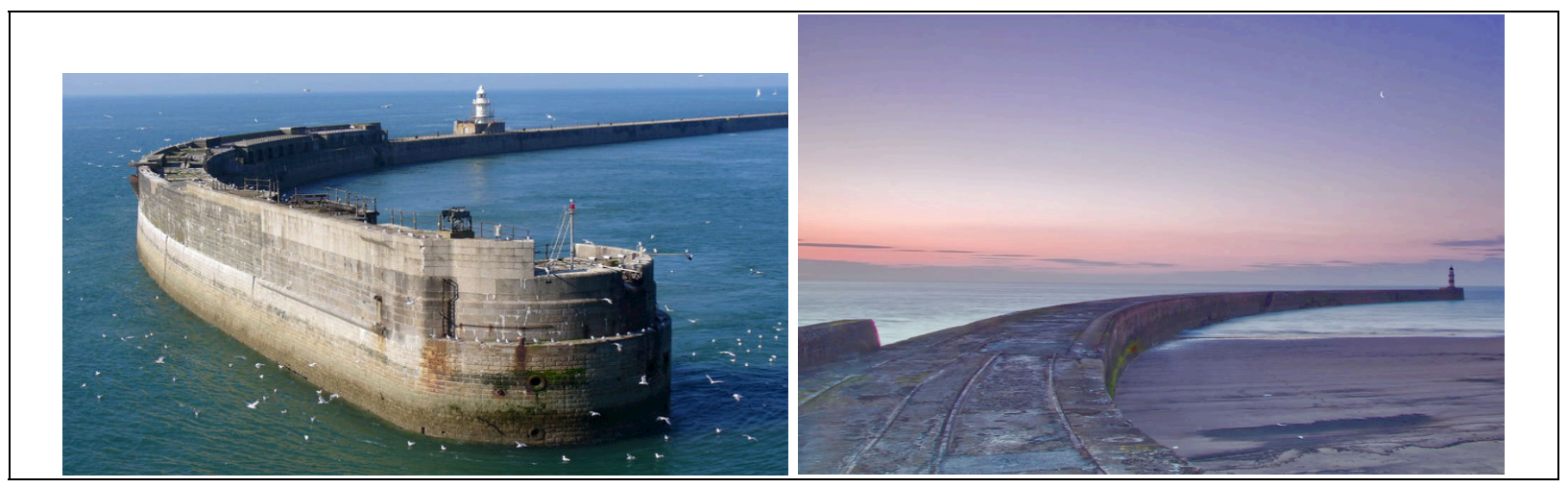

Figure 4: Dover (left) and Seaham (right)

The intention of this investigation is to make two reflections; the first, related with volumes of concrete and the discussion between mass and reinforced crown walls; the second, in view of the possibilities 
of replacing mass concrete by reinforced concrete in design, increasing slenderness and harmonising with nature in a more sustainable and lasting design.

\section{Bulky mass-concrete elements versus slender reinforced concrete}

In rubble mound breakwaters the top of a cross section very frequently ends in a slab, the main purposes of which are to seal the top surface, provide a roadway, and act as a support for port facilities; and a crown wall preventing and limiting overtopping and acting as a support to the armour layer should it be a slope. The crown wall is a rigid structure in contrast to a rubble mound. Damage here is of a fragile nature; usually the result of the action of just one sufficiently large wave (Silva et al, 1998). An analysis of the maritime climate (wave action and sea levels), the width of the esplanade and the breakwater foundations are also a cause for concern in its design. The small space available in a vertical breakwater may lead to trucks carrying cell fill, cranes for block laying, formwork and crown wall concreting equipment, capping beam elements and auxiliary areas which may be used as provisional quays, all coinciding.
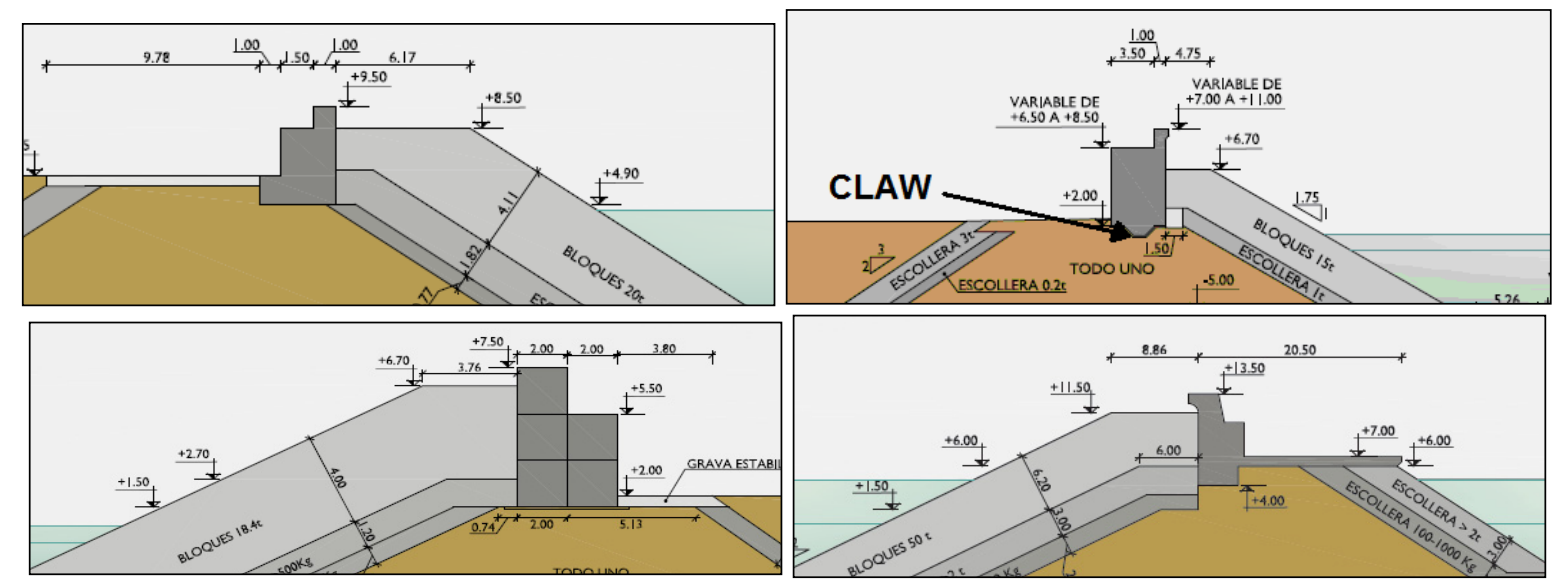

Figure 5: Different crown wall types for sloping breakwaters in Spain: Gijón (up, left), Barcelona (up, right), Castellón (down, left) and Bilbao (down, right) (Grau, 2012)

In sloping structures, concrete with large sized aggregate, low water/cement ratios and a dry consistency is normally used. It is directly poured on-site by a belt or ladle with powerful vibration equipment. The traditional sequence is to excavate the bottom slab (1); concrete the bottom with a rake or claw (2); concrete the central body (3), finish the protection of the main layer (4), concrete the higher parapet (5), with horizontal joints to ensure structural continuity and verticals to increase overturning safety. This work is usually performed with sliding formwork carriages of up to 15 metres. Despite being elements with a large volume of concrete and notwithstanding the modules' hydration heat, it is feasible and economically viable to use mass concrete. Results can be clearly observed in Spain using these criteria. A crown wall can be seen in steps like Gijón; with a "claw" in Barcelona; built by phases in Castellón, or with greater slenderness and continuity with the superstructure in Bilbao (Figure 5).

Reinforced concrete is more usual in vertical breakwaters, specially with caissons (Esteban et al, 2009). This is due to the fact that they occupy less space to allow the inner area berth to be used, to allow anchoring to the breakwater's body and because they need to be light enough to float. The use of reinforced concrete caissons began in the late nineteenth century in Europe and a few years later in Japan (Takahashi, 1996). Concreting is also performed in phases using carriages so that the length of the formwork is such that each caisson requires a whole number of places so that both joints coincide. Vertical joints must coincide to prevent fissures. The concrete's surface must be treated to prevent adherence. Edges must be chamfered. Galleries must be provided for pipes and services.

The problems of mass concrete (bulky mass concrete elements) solved with this type of construction are the cracking (Ferrol), due to concrete internal processes, and collapsing by the action of strong 
storms. It happened in Motril crown wall (Figure 6) due to the lack of steel reinforcement connection between the caisson and the parapet.

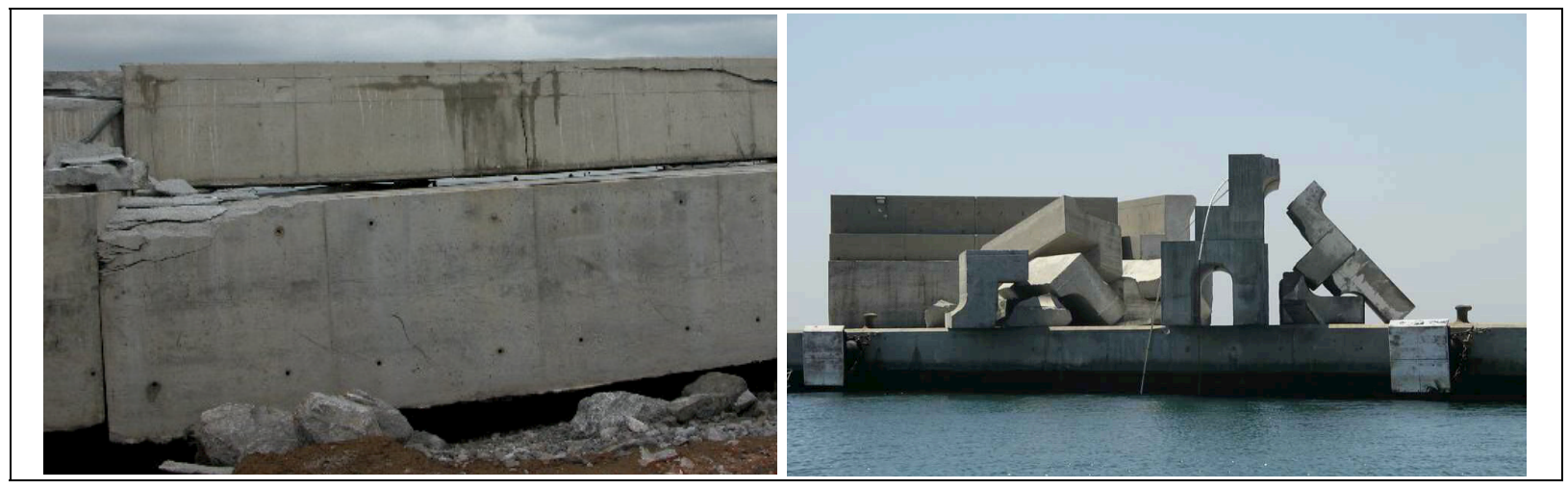

Figure 6: Problems in bulky mass concrete elements: cracking in Ferrol Prioriño Cape Harbour 2001 (left) and collapse in Motril Harbour 2004 (right)

In order for space to be gained, these circumstances allow the ratio of reinforcement to concrete to be increased provided monothilism with the caisson is guaranteed, facilitating the embodiment of aesthetic, artistic and cultural inheritance into a singular construction such as a breakwater.

The crown wall elements on rubble mounds are usually mass built with coarse aggregates, a low water/cement ratio and dry consistency. The approach in vertical breakwaters is clearly the use of reinforced concrete to increase accessibility and guarantee rigidity. These crown walls have a reinforcement of about $40 \mathrm{~kg}$ of steel per $\mathrm{m}^{3}$ of concrete. Another possibility is developing harmonious and more sophisticated designs. These can be arched shapes with $100 \mathrm{~kg} / \mathrm{m}^{3}$, curved with $120 \mathrm{~kg} / \mathrm{m}^{3}$ ("Gothic Parapet", Málaga) and hyper-elliptical or elliptical parapet with more than $120 \mathrm{~kg} / \mathrm{m}^{3}$ (Tazacorte Harbour, La Palma Island, 2001 and 2015) (Figure 7).

According to the cost of material, the two designs mentioned (conventional and sophisticated) are practically equivalent, since the second ones greatly reduce the volume of concrete (less than half), although the amount of reinforcement increases in a greater proportion. In sophisticated designs, the economical cost is slightly higher according to the Spanish experience, due to the more specialised workforce and the machinery and formwork with lower yield, enlarging the deadline for the works .

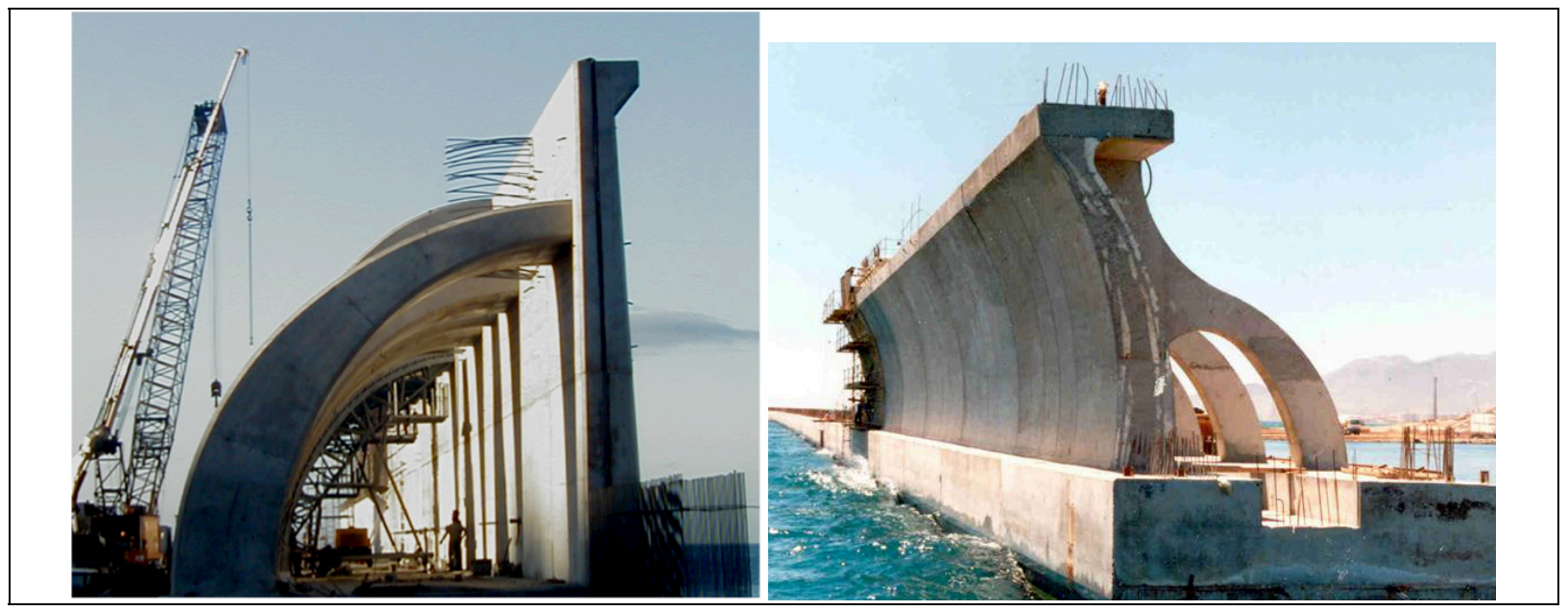

Figure 7: Slender reinforced concrete parapets. Tazacorte (left) and Málaga (right). 


\section{The Way to Aesthetics}

To approach the design of a crown wall from the origin of the cross section is not the same as drawing up an alternative when the construction process has already commenced. In this case, the aesthetic component proves unviable.

Let us make an historic and architectural approach. The Romanesque style represents own weight, gravity, the transmission of stresses in heavy, robust walls. The Gothic transmits its loads through arches and buttresses. The use of buttresses is obviously Málaga (Andalucia), the called "gothic parapet" (Gómez, 2001). The use of flying buttresses is Tazacorte (La Palma, Canary Islands). Both are in reinforced concrete.

In Tazacorte, these elements, plays of light and shadows, flat and curved with different buttresses, enable geometric elements to be played with, longer and shorter axes of ellipses and diaphanous views between every two arches measuring $6.60 \times 6.00 \mathrm{~m}$. This design, in turn, allows the headlight, the sea's sentinel, to be used as a monument to the lighthouse keeper whilst also seeking shapes in a sculpture-beacon (José Ramón Ortega design). This implies more difficulties in the formwork, and a longer duration of the works, as also happens in Malaga (Figure 8).

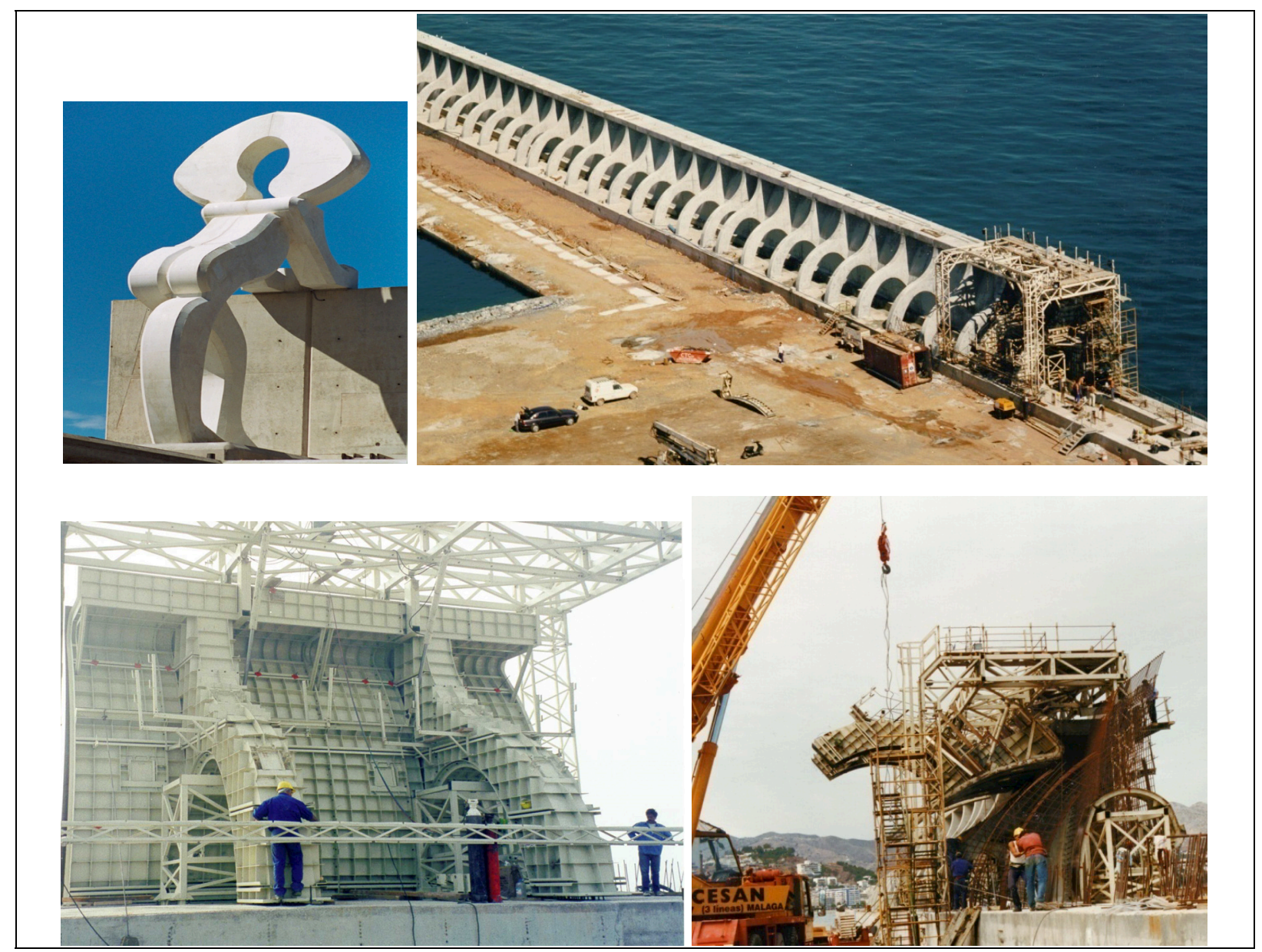

Figure 8: Port of Tazacorte beacon (up, left) and formwork in Málaga "gothic crown wall"

A similar conception in connection with the transmission of stresses, use of buttresses, arches and flying buttresses is the case of Malaga. Here is where the cruise liner terminal called for a revolutionary, aesthetic and luminous solution for the city, the centre of gravity of the Costa del Sol and of elite Spanish tourism. 
Over these last few years, Spanish engineering has continued taking risks in crown wall design. The case of the double parapet in Blanes (Girona) and Forum 2004 (Barcelona) where top of the structure is reduced to 10.5 and $9.5 \mathrm{~m}$ in the first case and 6 and $5 \mathrm{~m}$ in the second (Pita, 2013) (Figure 9).

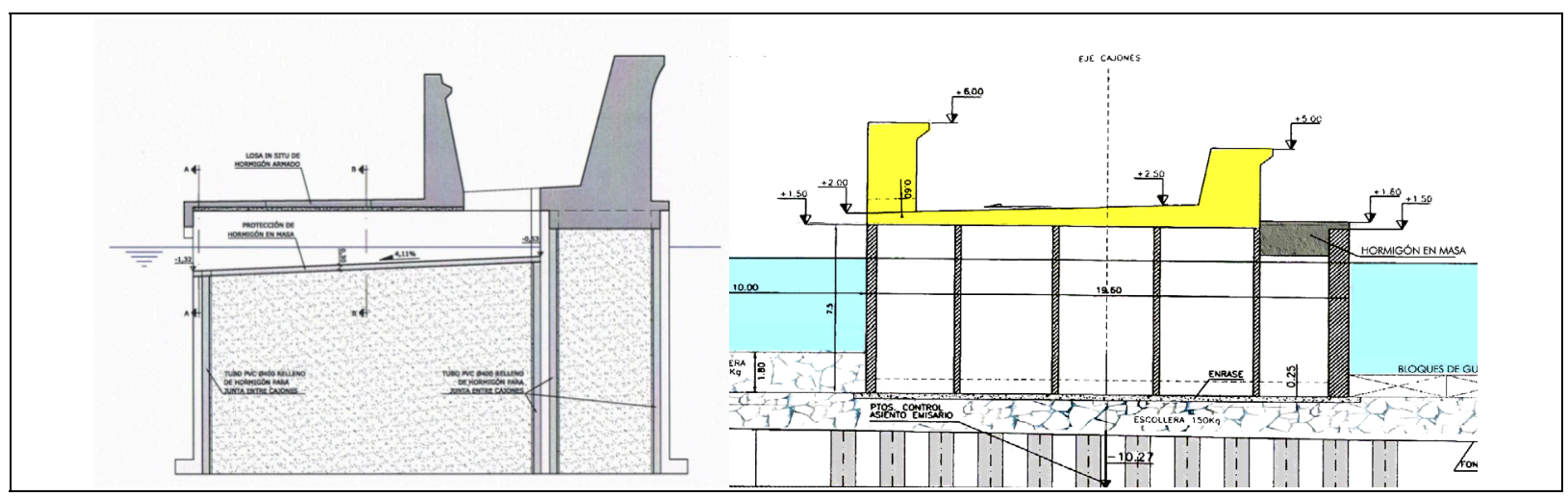

Figure 9: Double crown wall in Blanes 2013 (left) and Forum 2004 (right)

Another extraordinary contribution of Spanish maritime engineering to the design of breakwater crowning can be found in the Ciutadella outer breakwater in Minorca in 2008. Its purpose is to control long waves in the inner sea arm where the population and leisure and recreational activities are located. Hexagons on the same level allow the flow of the mass of water to be rhythmically and asymmetrically broken up. The design criteria in the area are a significant wave height of $6.55 \mathrm{~m}$. A conventional breakwater should be crowned at the +12 level, constituting a visual barrier not admissible from the environmental and landscape point of view. To resolve the problem, the crown was designed and built with two parallel vertical structures at the $+4.5 \mathrm{~m}$ level with a channel of $33 \mathrm{~m}$ wide and $14.50 \mathrm{~m}$ draught. The low crown wall of both breakwaters allows continuing enjoying the marine landscape seen from the coast. In a storm situation, the incident wave overtops the first barrier, pouring the mass of water into the lagoon where it loses much of its energy and reduces its wave height. When it hits the inner breakwater it does not exceed its crown wall providing the necessary shelter with an appropriate level of disturbance inside the basin. (Iribarren, 2012). That design and the Castellón Port breakwater in 2010, with the chambers and breather pipes are further clear examples of technological advances (Figure 10). In Castellón, this model was tested in CEDEX laboratory in a $45 \mathrm{~m} \times 6.5 \mathrm{~m} \times 1.5 \mathrm{~m}$ wave flume with $\mathrm{Hs}>7 \mathrm{~m}$ at $1 / 40$ Froude scale.

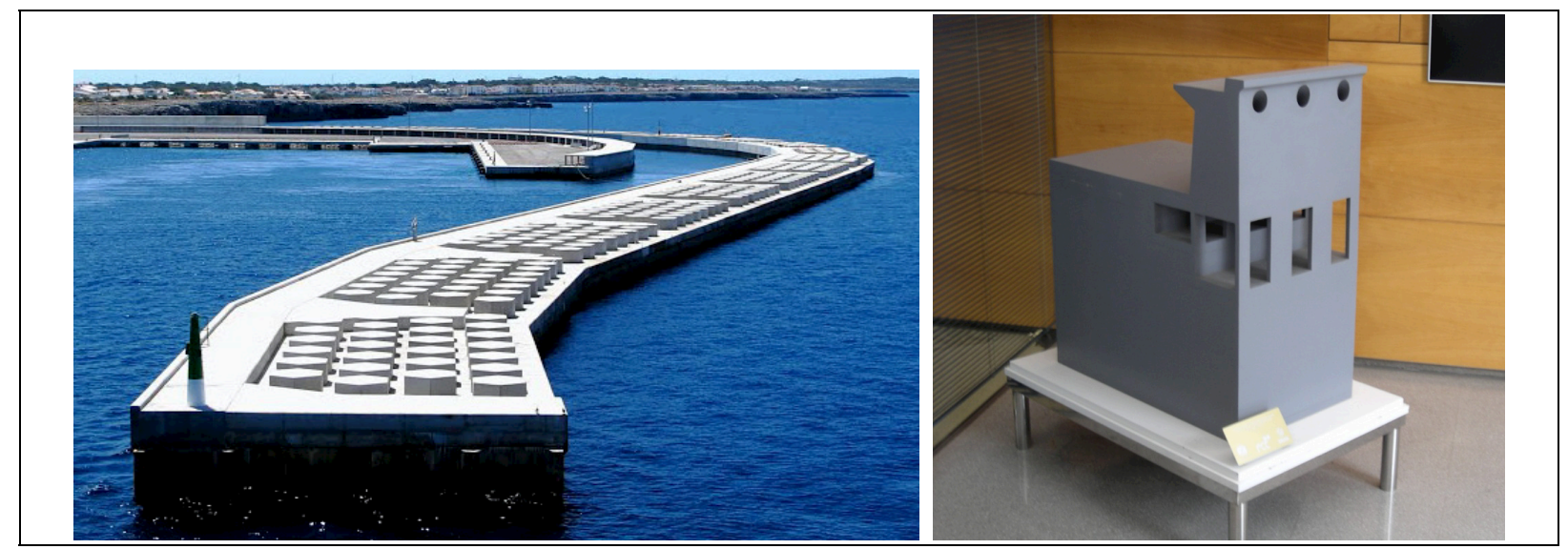

Figure 10: Ciutadella, Minorca 2008 (left) and Castellón 2010 (right)

We can find multiple innovative designs in the field of breakwaters the world over. The "Molhe Norte da Barra do Douro" in Porto (Portugal), which won the National Civil Engineering Award, the Secil Award, in 2009. This kind of design, with a wider crown wall can also be used for wave energy installations, such as the OWC installed in Mutriku (Basque Country, Spain) and the one studied in Porto (Henriques, 2013). In the case of the Porto breakwater, which has holes on the inner side of the crown wall that favour the expulsion of water in large storms, a row of natural parabolas are formed in 
these situations, pretty similar to the "constructed landscape" of the new elliptical crown wall of Tazacorte in 2015 (Martín-Antón, 2016)(Figure 11).

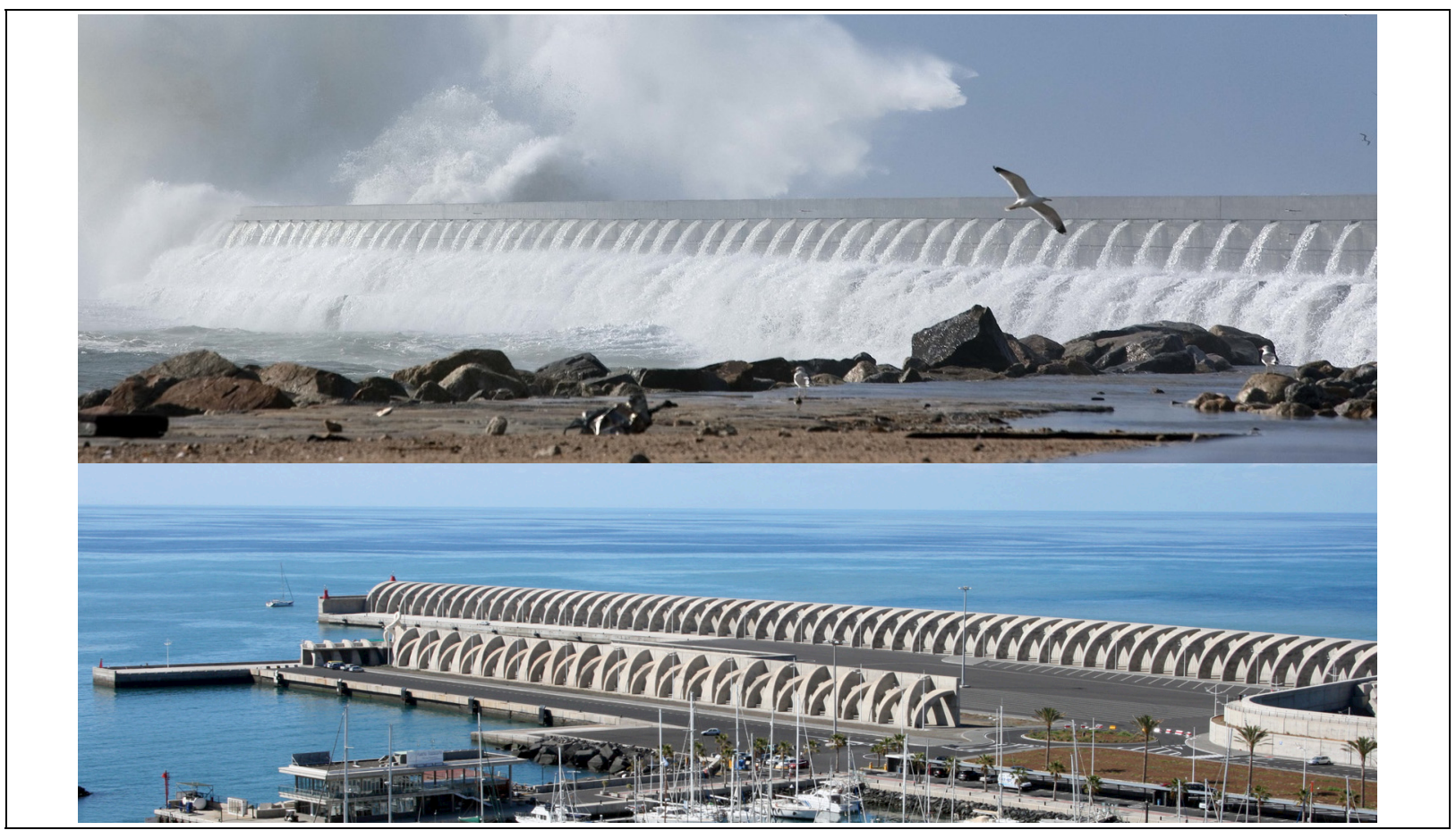

Figure 11: Landscape comparison: Natural parabolic waterfalls in "Molhe Norte da Barra do Douro" Porto (up) vs. elliptic crown wall in Tazacorte (down)

Another way to build curved breakwaters more easily is with circular reinforced caissons, as the case of the Brighton breakwater, similar to the "Duca degli Abruzzi" in Naples (Italy) or the Tanger Med breakwater, just to mention three of the numerous examples existing (Figure 12).

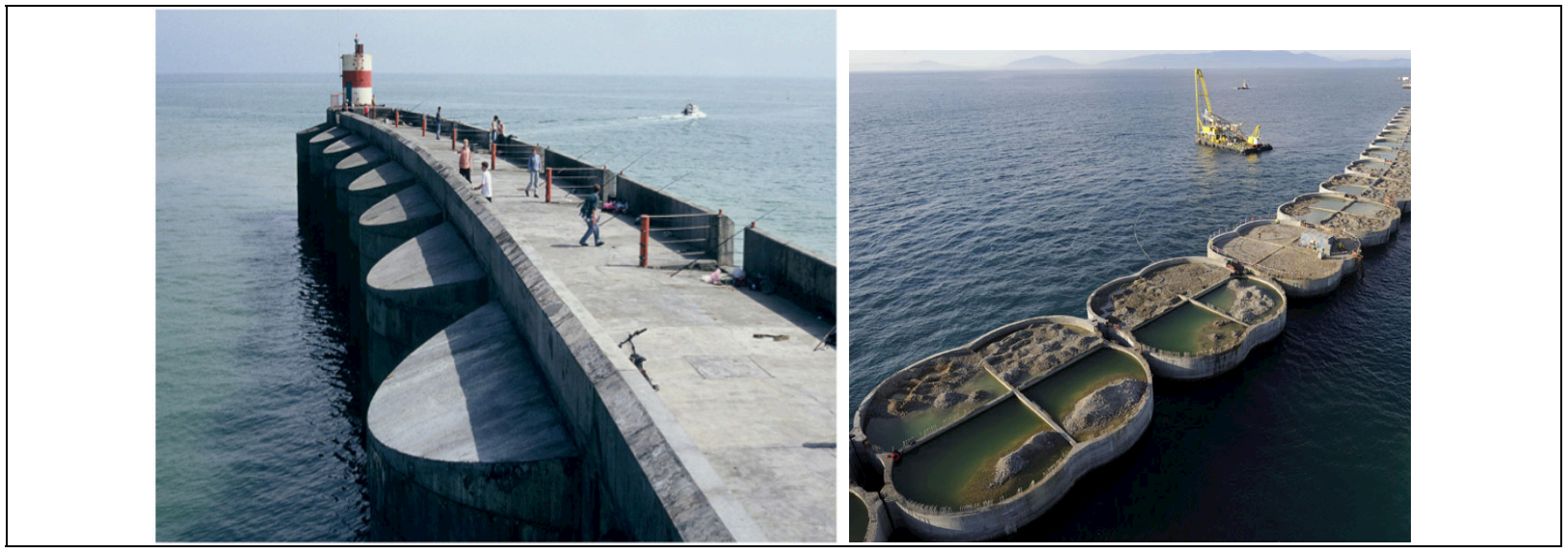

Figure 12: Brighton (left) and Tanger Med (right) reinforced caissons breakwaters

Apart from their main function, which is to stop wave's actions, breakwaters can also have other uses such as recreational spaces or promenades (Copeiro, 1998) On occasions, graphic designs in sea walls embody another aesthetic perspective in maritime constructions (Figure 13). The use of ornamental stone covering the concrete's visible parts making "de-luxe" masonry work also provides a cheerful look to breakwaters and quaysides when the evening closes in (Zumaia, Guipúzcoa, Basque Country). The parapet's large inside walls which, initially, form an insurmountable barrier between the city and the sea, may be full of life and form part of the urban landscape in a closer fashion, such as the case of the port of La Restinga (El Hierro, Canary Islands). 


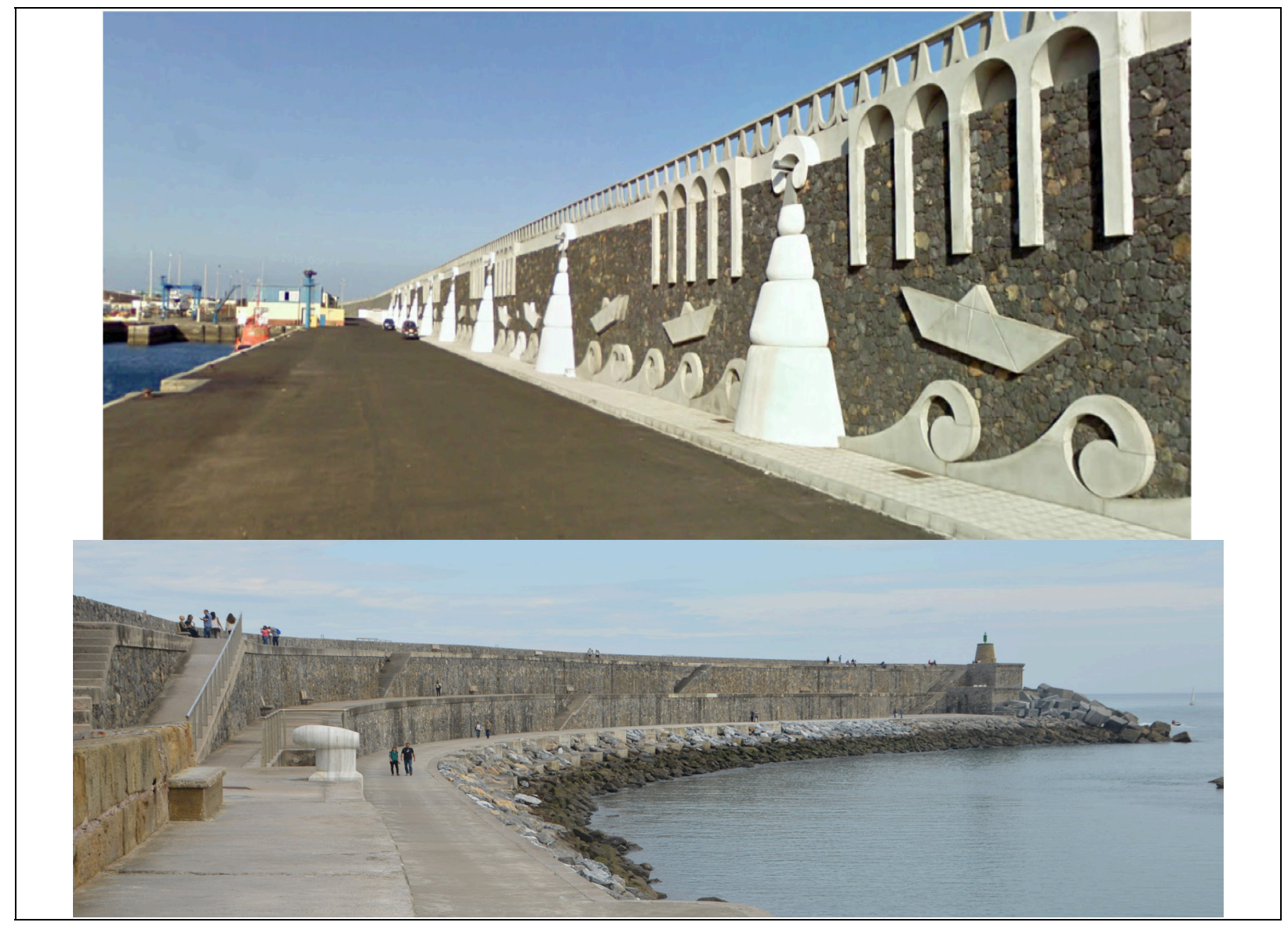

Figure 13: Aesthetics in the inner crown wall with other materials. Punta Restinga (up) and Zumaia (down)

Despite the difficulties of the maritime climate forces, i.e., the complications inherent to the functional requisites that these elements require, engineering has taken a step towards the sensitivity and aesthetic design lost during decades in enormous, disproportionate construction works. For example, Langosteira harbour in A Coruña has 138,000 blocks $\left(2.6\right.$ mill. $\mathrm{m}^{3}$ ) and a concrete superstructure of 0.81 mill. $\mathrm{m}^{3}$. Gijón, in north of Spain, has a concrete volume of 1.3 mill. $\mathrm{m}^{3}$ in blocks, $0.52 \mathrm{mill}^{3} \mathrm{~m}^{3}$ in caissons and 0.85 mill. $\mathrm{m}^{3}$ in superstructure (Grau, 2012). These latter only demonstrate "power" or "permanence" whilst not understanding the social nature of construction works and the possibilities they present in aspects of sustainability, harmony with the physical environment, minimal intrusion and landscape.

\section{Final Conclusions}

This investigation clearly presents these fundamental reflections:

- Crown walls can be bulky mass concrete elements built in sloping breakwaters, with low water/cement ratios and dry consistency concrete. Despite the existence of multiple shapes, the aesthetic contribution is scarce, basically because of the need to uphold the layer supports. Often they have cracking and problems of heat of hydration due to be large volumes of concrete.

- The need for space and the possibility of anchoring in vertical breakwaters allows plastic consistency reinforced concrete to be used. Tie steel-concrete ratio facilitates the aesthetic development of innovating solutions.

- In aesthetic solutions, the amount of reinforcement in these solutions is more than $100 \mathrm{~kg}$ of steel per $\mathrm{m}^{3}$ of concrete. 
- The change in the concept of stress (gravity) transmission by buttresses and arches allows for the play of light and shadows and the possibility of harmonious designs. Initial designs only represent a slightly higher cost in machinery and workforce.

- The "initial" design of crown walls, having controlled the ultimate limit (structural safety) and service states (functional safety), must also respond to aesthetic criteria.

- These are not new concepts since they can be found in magnificent constructions in many parts of the world, e.g., the United Kingdom, Italy, Japan and Spain.

\section{Acknowledgements}

To Dragados y Construcciones, S. A.; to Ferrovial and to "Puertos del Estado" (Spanish Port System) for references to maritime constructions built on the Spanish coastline over the last fifteen years. Also the authors express their gratitude to the "Fundación Agustín de Betancourt" for all the support given in the last two years.

\section{References}

British Standards Institution (BSI) (1991). BS 6349-7:1991 Maritime structures. Guide to the design and construction of breakwaters

Copeiro del Villar, E (1998) Pequeños diques rígidos para costas rocosas, Revista CementoHormigón, Instituto Español del Cemento y sus Aplicaciones (IECA), $n^{\circ} 787$ (El Hormigón en la Construcción de Puertos y Estructuras Marítimas), pp 856-864, ISSN 0008-8919

Esteban Lefler, F; Rey Romero, V. D (2009). Reinforced concrete caissons for port structures in Spain. Proceedings of the Institution of Civil Engineers. Maritime Engineering 162 Issue MA2. pp 7381. doi: $10.1680 /$ maen.2009.162 .2.73

EurOtop, 2016. Manual on wave overtopping of sea defences and related structures, www.overtopping-manual.com.

Gómez de la Fuente, J P (2001) Remodelación del Puerto de Málaga, Revista de Obras Públicas, vol.148, n 3411, pp. 67-73

Grau, J.I.; Arana, M; Gómez, G; Lope, A; Carretero, J.C. (2012) Diques de Abrigo en los puertos de Interés General Del Estado: años 1986 al 2011. Organismo Público Puertos del Estado. ISBN 9788488975805

Henriques, J.C.C. Cândido, J.J. Pontes, M.T. Falcão, A.F.O. (2013) Wave energy resource assessment for a breakwater-integrated oscillating water column plant at Porto, Portugal, Energy, Vol. 63 , pp. 52-60

Iribarren, J R; Verdugo, I; Cal, C; Berenguer, J M; Monsó, J L; Alomar, G (2012) Nuevo Puerto Exterior de Ciutadella. Estudios Náuticos para el Proyecto de Construcción y Entrada en Servicio, IV Congreso Nacional de la ATPYC - II Mediterranean Days of Coastal and Port Engineering.

Martín, F L; , Vidal, C; Losada, M A; Medina, R (1995). Un método para el cálculo de las acciones del oleaje sobre los espaldones de los diques rompeolas. Ingeniería del Agua, 2 (3): 37-52,

Martín-Antón, M; Negro, V.; del Campo, J.M., López-Gutiérrez, J.S., and Esteban M.D. (2016) El impacto de las obras públicas en España. Paisaje natural, construido y destruido. Revista Ingeniería Civil, CEDEX, n 184, ISSN: 0213-8468

Negro Valdecantos, V; López G, José Santos y Polvorinos Flors, J I (2013). Comparative study of breakwater crown wall - calculation methods. Proc. Institution of Civil Engineers, Maritime Engineering, v. 166 (n. 1); pp. 25-41. ISSN 1741-7597.

Pita Olalla, E; Darbra Román, J P; Rodríguez Castilla, A; Negrell Vila, O; Rivero F (2013) El Dique de Abrigo de la Ampliación del Puerto de Blanes. XII Jornadas Españolas de Ingeniería de Puertos y Costas. Cartagena - 2013

Rodríguez Gil, Á M.; Sánchez González, J F.; Gutiérrez Serret, R M y Negro Valdecantos, V (2015). Overtopping of harbour breakwaters: a comparison of semi-empirical equations, neural networks, and physical model tests, Jo. Hydraulic Research, pp. 1-14. ISSN 0022-1686.

Silva, R; Govaere, G; Martin, F (1998) A Statistical Tool for Breakwaters Design, Coastal Engineering n26, pp 1920-1933

Takahashi, S (1996) Design of Vertical Breakwaters. Port and Airport Research Institute, Japan. 